\title{
Actinoplanes toevensis sp. nov. and Actinoplanes tereljensis sp. nov., isolated from Mongolian soil
}

Correspondence

Ismet Ara

ara-ismet@nite.go.jp

\author{
Ismet Ara, ${ }^{1}$ Hideki Yamamura, ${ }^{2}$ Baljinova Tsetseg, $^{3}$ Damdinsuren Daram ${ }^{3}$ \\ and Katsuhiko Ando ${ }^{1}$
}

\author{
${ }^{1}$ Biotechnology Development Center, Department of Biotechnology (DOB), National Institute of \\ Technology and Evaluation (NITE), Kazusakamatari 2-5-8, Kisarazu, Chiba 292-0818, Japan \\ ${ }^{2}$ Division of Applied Biological Sciences, Interdisciplinary Graduate School of Medicine and \\ Engineering, University of Yamanashi, Takeda-4, Kofu 400-8511, Japan \\ ${ }^{3}$ Institute of Biology, Mongolian Academy of Sciences, Ulaanbaatar-51, Mongolia
}

\begin{abstract}
Two novel actinomycetes, designated MN07-A0368 ${ }^{\top}$ and $\mathrm{MNO} 7-\mathrm{A} 0371^{\top}$, were isolated from soil of Terelj, Töv Province, Mongolia, and subjected to phenotypic and genotypic characterization. They produced well-developed, non-fragmenting, extensively branched substrate hyphae from which oval to irregular sporangia were produced. Chemotaxonomic characteristics, i.e. cell wall diaminopimelic acid, whole-cell sugars, fatty acid components and major menaquinones, suggested that the two organisms belonged to the genus Actinoplanes. A comparative analysis of

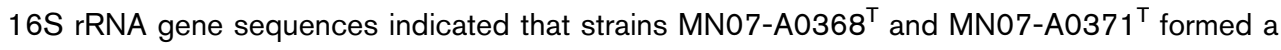
distinct clade within the genus and were closely related to the type strains of: Actinoplanes ferrugineus (97.7\% sequence similarity); Actinoplanes brasiliensis (97.7-97.8\%); Actinoplanes deccanensis (97.6-97.9\%); Actinoplanes durhamensis (96.9-97.0\%); and Actinoplanes globisporus (96.5-96.8\%). Strains MN07-A0368 ${ }^{\top}$ and MN07-A0371 ${ }^{\top}$ could be differentiated from each other and from strains of closely related species of the genus Actinoplanes by DNADNA hybridization, physiological and biochemical characteristics, fatty acid composition, and whole-cell sugar components. The broad range of phenotypic and genetic characters supported the suggestion that these strains represent two novel species of the genus Actinoplanes, for

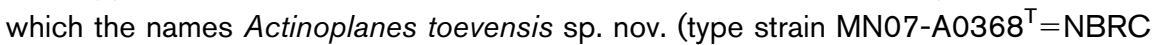
$105298^{\top}=$ VTCC D9-11 ${ }^{\top}$ ) and Actinoplanes tereljensis sp. nov. (type strain MN07-A0371 ${ }^{\top}$ $=$ NBRC $105297^{\top}=$ VTCC D9-10 ${ }^{\top}$ ) are proposed.
\end{abstract}

The genus Actinoplanes Couch 1950 emend. Stackebrandt and Kroppenstedt 1988 belongs to the family Micromonosporaceae Krassil'nikov 1938 emend. Stackebrandt et al. 1997. The type species of the genus Actinoplanes is Actinoplanes philippinensis Couch 1950 and, at the time of writing, the genus comprised 24 species with validly published names. A detailed phenotypic analysis of the genus has been given by Goodfellow et al. (1990), who determined the chemotaxonomic and phenotypic characteristics of species of the genus Actinoplanes and reported that chemical and numerical taxonomic data supported the integrity of the genus. Furthermore, a comprehensive phylogenetic analysis of the genus has been given by Tamura \& Hatano (2001).

Abbreviations: DAP, diaminopimelic acid; SEM, scanning electron microscopy.

The GenBank/EMBL/DDBJ accession numbers for the 16S rRNA gene sequences of strains MN07-A0368 ${ }^{\top}$ and MN07-A0371 ${ }^{\top}$ are AB468943 and AB468944, respectively.
Mongolia is one of the biggest countries in Asia and has recently attracted the attention of naturalists and other researchers in their search for actinomycetes (Norovsuren et al., 2007) as a potential source of bioactive secondary metabolites. Mongolia also has a preserved ecosystem with rich biodiversity and, for this reason, the Department of Biotechnology, National Institute of Technology and Evaluation, Chiba, Japan, conducted research entitled 'Taxonomic and Ecological Studies of Actinomycetes' in Mongolia. Samples of grassland soil were collected in July, 2007, from Terelj National Park, Töv Province, Ulaanbaatar, Mongolia. Samples were dried at room temperature for 5-7 days and then inoculated using the rehydration/centrifugation method (Hayakawa et al., 2000) on humic acid-vitamin agar (Hayakawa \& Nonomura, 1987) containing trimethoprim $\left(20 \mathrm{mg} \mathrm{l}^{-1}\right)$ and nalidixic acid $\left(10 \mathrm{mg} \mathrm{l}^{-1}\right)$. Two strains, designated MN07-A0368

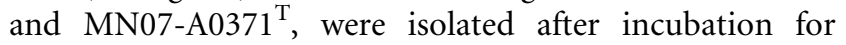
about 2-3 weeks at room temperature. Following isolation, strains MN07-A0368 ${ }^{\mathrm{T}}$ and MN07-A0371 ${ }^{\mathrm{T}}$ were maintained 
on yeast extract-soluble starch medium [YS medium, $\mathrm{pH} 7.3$, containing $\left(\mathrm{l}^{-1}\right): 2 \mathrm{~g}$ yeast extract, $10 \mathrm{~g}$ soluble starch and $15 \mathrm{~g}$ agar] and Bennett agar (yeast extract, $0.1 \%$; beef extract, $0.1 \%$; NZ amine, type A, $0.2 \%$; maltose monohydrate, $1.0 \%$; and agar, $1.5 \%$; $\mathrm{pH} 7.3$ ) (Jones, 1949); strains were also kept as hyphal fragments and spore suspensions in $20 \%(\mathrm{v} / \mathrm{v})$ glycerol at $-80{ }^{\circ} \mathrm{C}$.

For comparative purposes, Actinoplanes ferrugineus NBRC $15555^{\mathrm{T}}$, Actinoplanes brasiliensis NBRC $13938^{\mathrm{T}}$, Actinoplanes deccanensis NBRC $13994^{\mathrm{T}}$, Actinoplanes globisporus NBRC $13912^{\mathrm{T}}$ and Actinoplanes durhamensis NBRC $14914^{\mathrm{T}}$ were included in the study because phylogenetic analysis with all recognized species of the genus Actinoplanes indicated that these strains were most closely related to strains MN07-A0368 ${ }^{\mathrm{T}}$ and MN07A0371 ${ }^{\mathrm{T}}$. All seven strains that were tested were grown on ISP media 2 to 7 (Shirling \& Gottlieb, 1966), Bennett agar and YS medium at $28{ }^{\circ} \mathrm{C}$ for 3 weeks (Table 1) and cultural characteristics were observed. Colours of the substrate hyphae were determined from the reverse side as described by Shirling \& Gottlieb (1966). Cell morphology was observed under a light microscope and by scanning electron microscopy (SEM). Spore motility was assessed by light microscopic observation of cells suspended in phosphate buffer ( $\mathrm{pH} 7.0,1 \mathrm{mM})$. For SEM, agar blocks containing the organisms (cultivated on water agar medium for 14 days at $28{ }^{\circ} \mathrm{C}$ ) were fixed with $1 \%$ osmium tetroxide vapour and dried samples were sputter-coated and viewed by SEM (Tamura et al., 1994).

Morphological characteristics of strains MN07-A0368 ${ }^{\mathrm{T}}$ and MN07-A0371 ${ }^{\mathrm{T}}$ were consistent with those of members of the genus Actinoplanes. Formation of sporangia was observed on water agar medium in strains MN07-A0368 ${ }^{\mathrm{T}}$ and MN07-A0371 ${ }^{\mathrm{T}}$ (Fig. 1). Fragmentation of substrate mycelium and formation of aerial mycelium was not observed. Strain MN07-A0368 ${ }^{\mathrm{T}}$ produced numerous globose sporangia, whereas strain $\mathrm{MN} 07-\mathrm{A} 0371^{\mathrm{T}}$ formed irregular sporangia directly on the agar surface (Fig. 1a, c). Each sporangium was supported by a thick, vertically oriented substrate hypha, the sporangiophore (Fig. 1b, d). A thin sporangial envelope enclosed the mass of spherical to ovoid spores with smooth surfaces and the spores were motile. All of the strains studied, i.e. MN07-A0368 ${ }^{\mathrm{T}}$, MN07-A0371 ${ }^{\mathrm{T}}$ and the five selected reference type strains, showed poor growth on water agar, but most strains showed moderate to good growth on the other media tested (Table 1). A pale pinkish to reddish brown soluble pigment was formed on ISP 7 by MN07-A0368 ${ }^{\mathrm{T}}$, MN07A0371 ${ }^{\mathrm{T}}$ and A. ferrugineus NBRC $15555^{\mathrm{T}}$. Strains MN07A0368 ${ }^{\mathrm{T}}$ and MN07-A0371 ${ }^{\mathrm{T}}$ could be differentiated from closely related type strains by growth intensity, substrate mycelium colour and production of diffusible pigments on different agar media (Table 1).

Physiological and biochemical characteristics of strains MN07-A0368 ${ }^{\mathrm{T}}$ and MN07-A0371 ${ }^{\mathrm{T}}$ were determined after incubation at $28{ }^{\circ} \mathrm{C}$ for 3 weeks. $\mathrm{NaCl}$ tolerance was examined on YS medium prepared with $0,1,2,3,4,5,6,7$ and $8 \%(\mathrm{w} / \mathrm{v}) \mathrm{NaCl}$. Growth at different temperatures was examined on YS medium incubated at 4, 10, 15, 20, 25, 28, 30, 37, 40 and $45^{\circ} \mathrm{C}$. ISP medium 8 (full strength) (Gordon \& Mihm, 1957) was used to test for nitrate reduction. Decomposition of urea was determined on Christensen's urea agar containing $2 \%$ urea (Gordon et al., 1974). Degradation of casein and other compounds $(0.5 \%$ final concentration) was determined using YS medium as the modified basal medium (Gordon et al., 1974). Catalase activity was detected by dropping $3 \% \mathrm{H}_{2} \mathrm{O}_{2}$ onto welldeveloped colonies on agar plates and observing any gas bubbles produced. Other biochemical analyses were performed using the modified methods of Kloos et al. (1974) and by using commercial biochemical test kits such as the API Coryne test system (bioMérieux). Constitutive enzymic activities were tested using an API ZYM test kit according to the manufacturer's instructions (bioMérieux; Humble et al., 1997). Detailed results are given in the species description and in Table 2. Each strain showed a characteristic pattern with the API ZYM and API Coryne test kits (Table 2). The novel isolates could be differentiated from many close phylogenetic neighbours using several agar-based and traditional biochemical tests (e.g. hydrolysis of urea, starch, Tween 20 and Tween 80, degradation of calcium malate, casein and tyrosine, gelatin liquefaction, and nitrate reduction), and by their tolerance to $\mathrm{NaCl}$, growth temperature, growth $\mathrm{pH}$, and API ZYM and API Coryne test kit results (Table 2). Based on API ZYM results, all strains were positive for cystine arylamidase, $\beta$-galactosidase, $N$-acetyl- $\beta$-glucosamine and $\alpha$-fucosidase, but negative for trypsin. Based on API Coryne results, all strains were positive for pyrazinamidase, alkaline phosphatase, $\beta$-galactosidase, $\alpha$-glucosidase and $\beta$-glucosidase, and hydrolysis of gelatin, D-glucose and sucrose, but negative for pyrrolidonyl arylamidase.

Genomic DNA was extracted and purified as described by Marmur (1961) and Saito \& Miura (1963), but with a slight modification: after lysis, $20 \%$ SDS and protease $\mathrm{K}$ were used to denature proteins and phenol:chloroform: isoamyl alcohol $(25: 24: 1$, by vol.) was used to remove denatured proteins. 16S rRNA gene sequences were analysed as described by Tamura \& Hatano (2001). Sequence analysis was performed with an ABI Prism BigDye Terminator cycle sequencing kit (PE Applied Biosystems) and an automatic DNA sequencer (model 3130 Genetic Analyzer: PE Applied Biosystems). BLAST analysis (Altschul et al., 1990) was used to compare the 16S rRNA gene sequences of strains MN07-A0368 ${ }^{\mathrm{T}}$ and MN07-A0371 ${ }^{\mathrm{T}}$ with sequences from the NCBI nucleotide database and sequence alignments were generated using the program CLUSTAL_X (Thompson et al., 1997) with corresponding sequences (available in DDBJ/EMBL/GenBank) from all type strains in the genus Actinoplanes. The evolutionary distance matrices (Kimura two-parameter model) were calculated and phylogenetic trees were inferred using the neighbour-joining method in the 
Table 1. Cultural characteristics of $M N 07-A 0368^{\top}, M N 07-A 0371^{\top}$ and related Actinoplanes species

Strains: 1, A. toevensis sp. nov. MN07-A0368 ${ }^{\mathrm{T}} ; 2$, A. tereljensis sp. nov. MN07-A0371 ${ }^{\mathrm{T}}$; 3, A. ferrugineus NBRC $15555^{\mathrm{T}}$; 4, A. globisporus NBRC $13912^{\mathrm{T}} ; 5$, A. brasiliensis NBRC $13938^{\mathrm{T}} ; 6$, A. deccanensis $\mathrm{NBRC} 13994^{\mathrm{T}} ; 7$, A. durhamensis $\mathrm{NBRC} 14914^{\mathrm{T}}$. No aerial mycelia were formed on any agar media tested. + +, Good growth; +, moderate growth; \pm , poor growth; Mod, moderate; B, brown; C, colourless; O, orange; R, red; Y, yellow. Numbers in parentheses are colour codes from a mycological colour chart (Rayner, 1970).

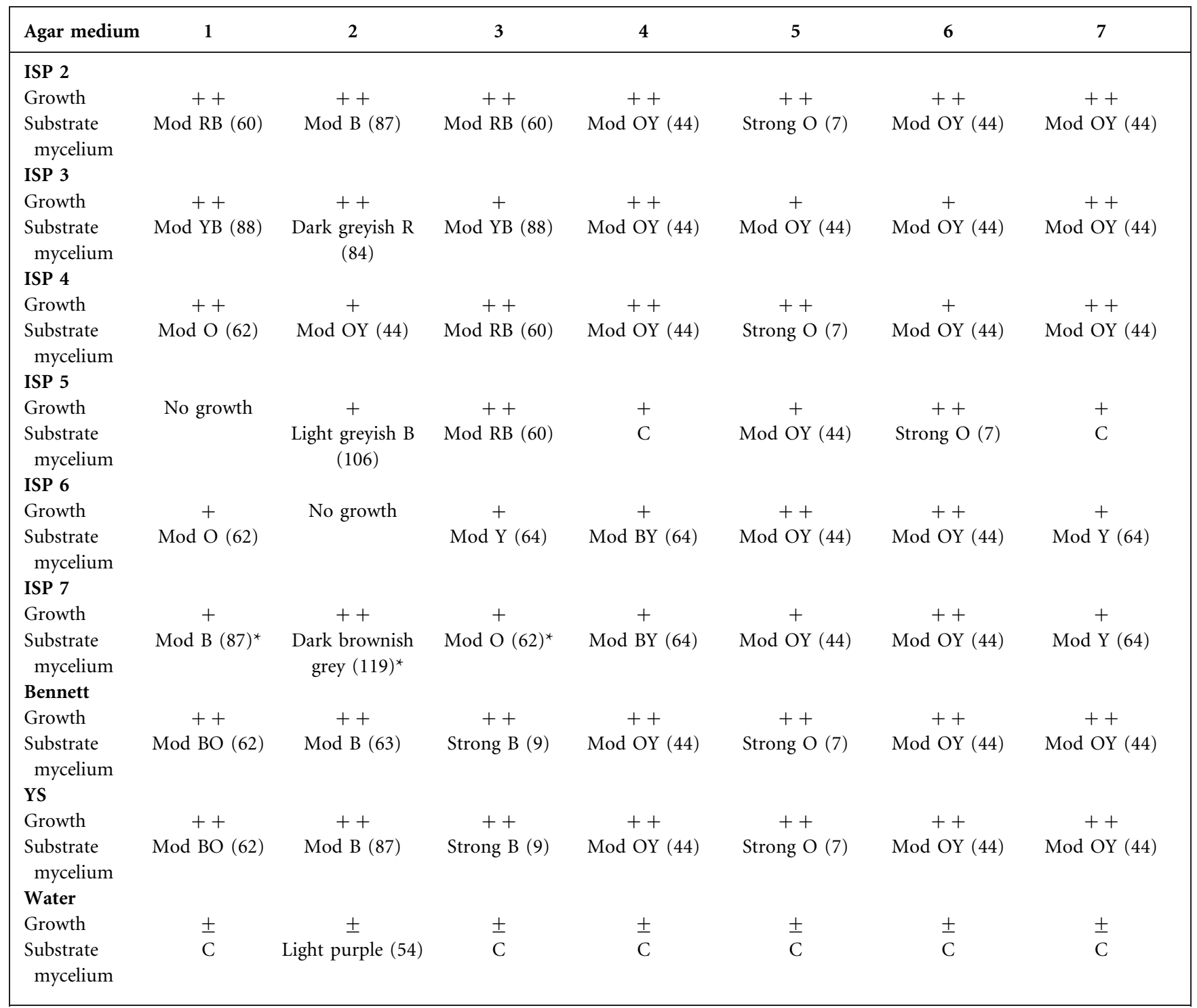

${ }^{\star}$ Pale pinkish to reddish brown diffusible pigments observed on ISP 7 medium.

CLUSTAL_X package and the minimum-evolution (Rzhetsky \& Nei, 1992) and maximum-parsimony (Eck \& Dayhoff, 1966) methods; neighbour-joining (Saitou \& Nei, 1987) tree-making algorithms in the MEGA4 package (Tamura et al., 2007) were used. Evolutionary distances were computed using the maximum composite likelihood method (Tamura et al., 2004). Stability of the resultant tree topologies was evaluated by bootstrap analysis (Felsenstein, 1985) based on the neighbour-joining dataset of 1000 resamplings using the CLUSTAL_X and MEGA4 packages. The $\mathrm{G}+\mathrm{C}$ content of the DNA was determined by HPLC as described by Mesbah et al. (1989). DNA-DNA hybridization was performed as described by Ezaki et al. (1988, 1989).

It is evident from Fig. 2 that strains MN07-A0368 ${ }^{\mathrm{T}}$ and MN07-A0371 ${ }^{\mathrm{T}}$ formed a distinct clade in the genus Actinoplanes 16S rRNA gene tree together with strains of closely related species: A. ferrugineus IMSNU $22125^{\mathrm{T}}$ (97.7\% similarity); A. brasiliensis DSM 43805 ${ }^{\mathrm{T}}$ (97.797.8\%); A. deccanensis NBRC $13994^{\mathrm{T}}$ (97.6-97.9\%); A. durhamensis IMSNU $22124^{\mathrm{T}}$ (96.9-97.0\%); and A. globis- 

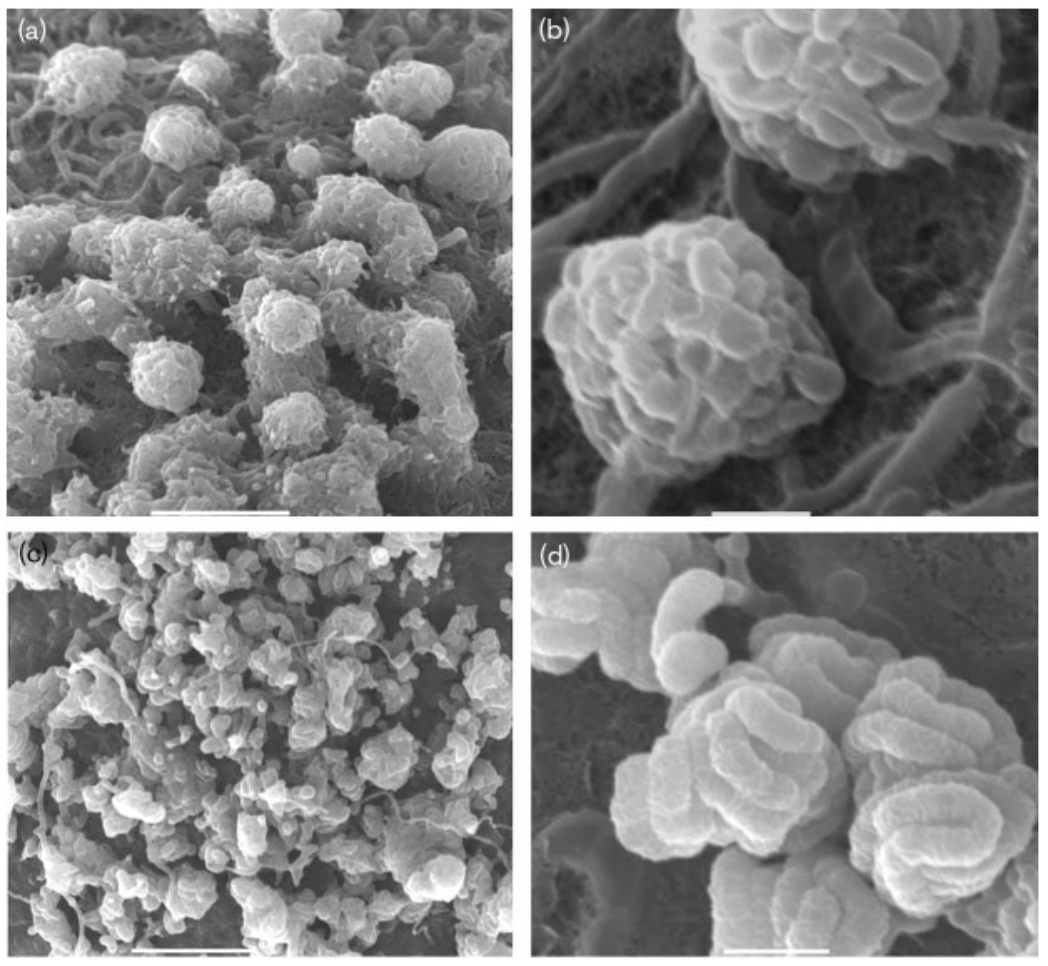

Fig. 1. Scanning electron micrographs of strains MN07-A0368 ${ }^{\top}(a, b)$ and MN07$A 0371^{\top}(c, d)$. Cultivation was carried out on water agar medium at $28^{\circ} \mathrm{C}$ for 14 days. (a, c) Sporophore and sporangia (indicated by arrows). (b, d) Detail of sporangium and spore chains (indicated by arrow). Bars: $a, 10 \mu \mathrm{m} ; \mathrm{b}$, $2 \mu \mathrm{m}$;, $10 \mu \mathrm{m} ; \mathrm{d}, 2 \mu \mathrm{m}$.

porus NBRC $13912^{\mathrm{T}}$ (96.5-96.8\%). 16S rRNA gene sequence similarity between strains MN07-A0368 ${ }^{\mathrm{T}}$ and MN07-A0371 ${ }^{\mathrm{T}}$ was $99.2 \%$; this association was supported by all of the tree-making algorithms with low bootstrap value (Fig. 2). DNA-DNA hybridization values between the novel isolates and the type strains of closely related Actinoplanes species were determined (Table 3). DNA relatedness between strains $\mathrm{MN} 07-\mathrm{A} 0368^{\mathrm{T}}$ and MN07$\mathrm{A} 0371^{\mathrm{T}}$ ranged from 34 to $42 \%$ (Table 3 ). Consequently, our isolates were identified as representatives of two species. DNA relatedness values between the novel isolates and all Actinoplanes type strains studied were less than $56 \%$, which is below the $70 \%$ cut-off point recommended for the delineation of genomic species (Wayne et al., 1987). Therefore, strains MN07-A0368 ${ }^{\mathrm{T}}$ and MN07A037 ${ }^{\mathrm{T}}$ differed from all closely related type strains of Actinoplanes species (Table 3 ). The DNA G $+\mathrm{C}$ content of the novel isolates was $70.6 \mathrm{~mol} \%$.

Strains MN07-A0368 ${ }^{\mathrm{T}}$ and MN07-A0371 ${ }^{\mathrm{T}}$ were examined for key chemical markers to determine whether they had a chemotaxonomic profile that was consistent with classification in the genus Actinoplanes. The required biomass was harvested using centrifugation of cell mass from yeast extract-glucose (YG; yeast extract, $10 \mathrm{~g} \mathrm{l}^{-1}$; glucose, $10 \mathrm{~g} \mathrm{l}^{-1}$; pH 7.0) broth grown for 2 weeks at $28{ }^{\circ} \mathrm{C}$ in a shaker incubator. The harvested cell mass was washed twice with sterile distilled water and freeze-dried. Biomass for quantitative fatty acid analysis was collected from fresh agar plates incubated for 2 weeks at $28^{\circ} \mathrm{C}$. Cellular fatty acid profiles were determined by GLC (MIDI) using the standard protocol (Sasser, 1990). As observed previously, A. ferrugineus, A. brasiliensis, A. deccanensis, A. durhamensis and A. globisporus contained large amounts of iso- and anteiso-branched fatty acids relative to other species of the genus Actinoplanes. Strains MN07-A0368 ${ }^{\mathrm{T}}$ and MN07$\mathrm{A} 0371^{\mathrm{T}}$ also produced relatively large proportions of isoand anteiso-branched fatty acids, predominantly iso- $\mathrm{C}_{16: 0}$, anteiso- $C_{17: 0}$, iso- $C_{15: 0}$ and anteiso- $C_{15: 0}$. Strains MN07A0368 ${ }^{\mathrm{T}}$ and $\mathrm{MN} 07-\mathrm{A} 0371^{\mathrm{T}}$ could be differentiated from the closely related Actinoplanes species A. ferrugineus and A. globisporus by the presence of high proportions of $\mathrm{C}_{16: 0}$, $\mathrm{C}_{18: 0}$, 9-methyl $\mathrm{C}_{16: 0}$ and iso- $\mathrm{C}_{17: 0}$. The complete cellular fatty acid profiles of strains MN07-A0368 ${ }^{\mathrm{T}}, \mathrm{MN} 07-\mathrm{A} 0371^{\mathrm{T}}$, A. ferrugineus NBRC $15555^{\mathrm{T}}$, A. brasiliensis $\mathrm{NBRC} 13938^{\mathrm{T}}$, A. deccanensis NBRC $13994^{\mathrm{T}}$, A. globisporus $\mathrm{NBRC} 13912^{\mathrm{T}}$ and A. durhamensis NBRC $14914^{\mathrm{T}}$ determined in this study can be found in Table 4.

Menaquinone analysis was carried out by the method of Minnikin et al. (1984). Quinones were extracted from $100 \mathrm{mg}$ freeze-dried cell material using chloroform/methanol and separated by TLC on silica gel, removed from the plate and further analysed by HPLC. Menaquinones were MK-9 $\left(\mathrm{H}_{6}\right)$ (accounting for $97 \%$ of the total) and MK$9\left(\mathrm{H}_{8}\right)(3 \%)$ for strain MN07-A0368 ${ }^{\mathrm{T}}$ and $\mathrm{MK}-9\left(\mathrm{H}_{6}\right)$ $(85 \%)$ and MK-9 $\left(\mathrm{H}_{8}\right)(15 \%)$ for strain MN07-A0371 ${ }^{\mathrm{T}}$ (Table 5). Whole-cell sugars were analysed as described by Staneck \& Roberts (1974). The diaminopimelic acid (DAP) isomer in the peptidoglycan was analysed as described by Nozawa et al. (2007). Phospholipids and mycolic acids were analysed as described previously 
Table 2. Physiological and biochemical properties that differentiate strains $M N 07-A 0368^{\top}$ and $M N 07-A 0371^{\top}$ from related Actinoplanes species

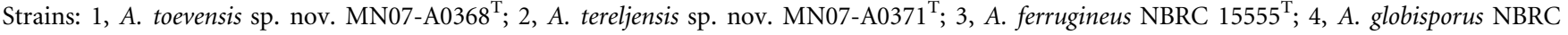
$13912^{\mathrm{T}} ; 5$, A. brasiliensis NBRC $13938^{\mathrm{T}} ; 6$, A. deccanensis NBRC $13994^{\mathrm{T}} ; 7$, A. durhamensis NBRC $14914^{\mathrm{T}}$. + , Positive; - , negative; \pm , weakly positive.

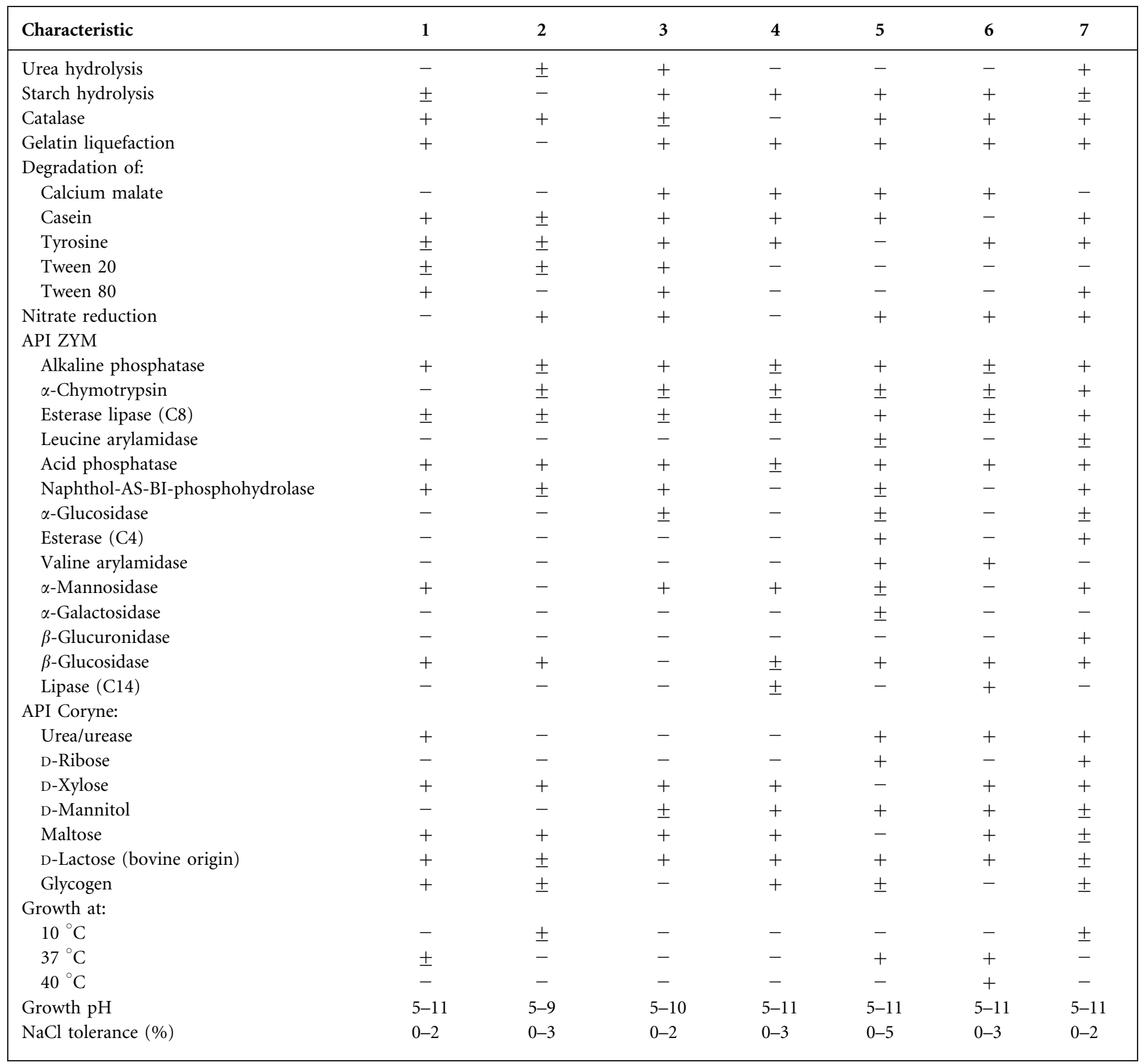

(Tamura et al., 1994). The polar lipid profile contained diphosphatidylglycerol, phosphatidylethanolamine, phosphatidyl- $N$-methylethylethanolamine and phosphatidylinositol, but phosphatidylcholine and phosphatidylglycerol were not detected (phospholipid type PII; Lechevalier et al., 1977). The complete chemotaxonomic profiles of strains MN07-A0368 ${ }^{\mathrm{T}}$, MN07-A0371 ${ }^{\mathrm{T}}$, A. ferrugineus NBRC $15555^{\mathrm{T}}, A$. brasiliensis NBRC $13938^{\mathrm{T}}, A$. deccanensis NBRC $13994^{\mathrm{T}}$, A. globisporus NBRC $13912^{\mathrm{T}}$ and $A$. durha- mensis NBRC $14914^{\mathrm{T}}$ determined in this study can be found in Table 5.

Physiological and chemotaxonomic analyses indicated that strains MN07-A0368 ${ }^{\mathrm{T}}$ and MN07-A0371 ${ }^{\mathrm{T}}$ belong to the genus Actinoplanes; 16S rRNA gene sequence and DNADNA hybridization analyses indicated that they represent two novel species. Phenotypic characters and fatty acid analysis are also consistent with novel species status for 


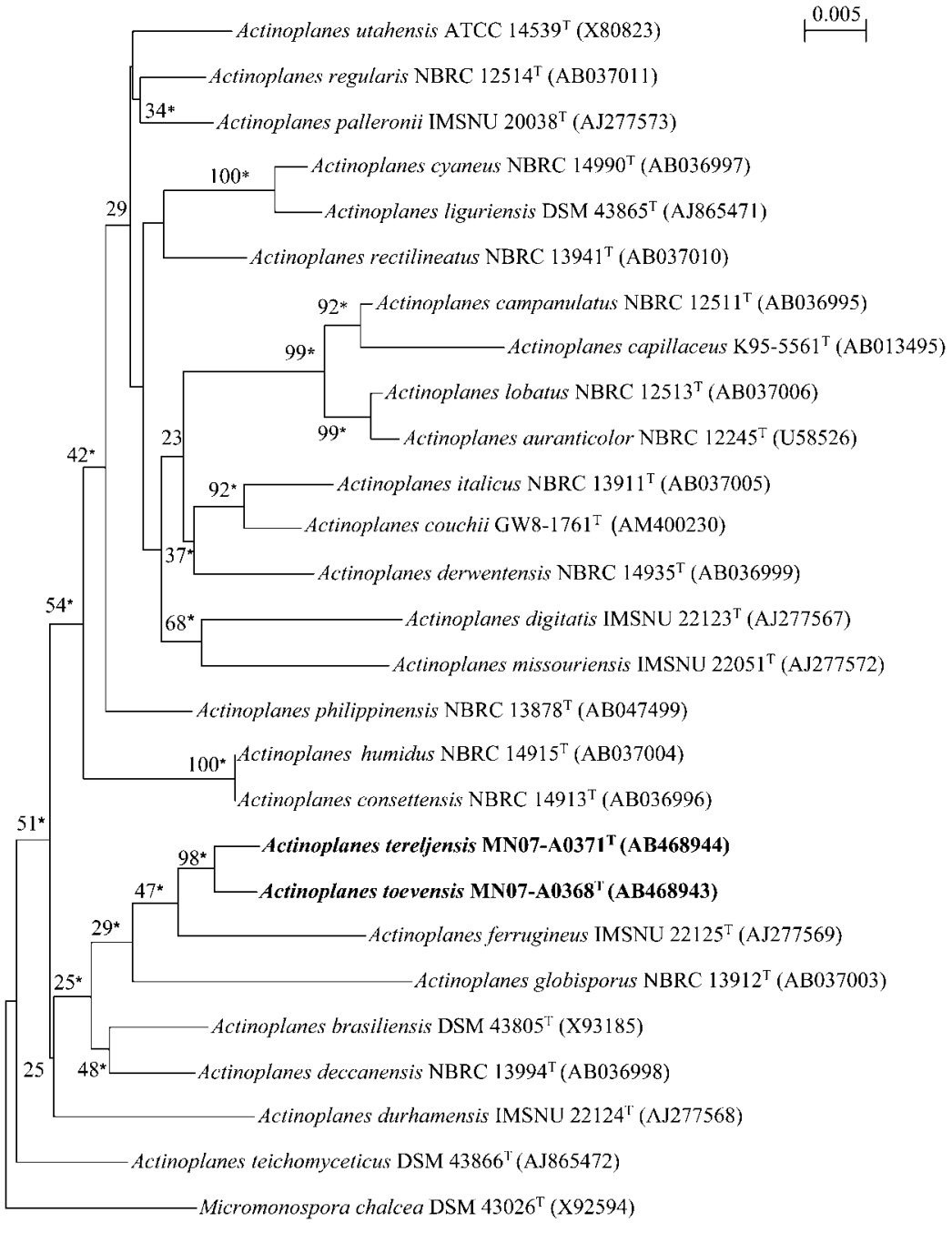

Fig. 2. Neighbour-joining phylogenetic tree based on 16S rRNA gene sequences showing the relationship between strains MN07A0368 ${ }^{\top}$ and MN07-A0371 ${ }^{\top}$ and members of the genus Actinoplanes. Asterisks indicate phyletic lines that were recovered using minimum-evolution, maximum-parsimony and neighbour-joining tree-making algorithms. Bootstrap values (\%) based on 1000 replications are given at branching points. Bar, 0.005 nt substitutions per nucleotide position. these two strains. Therefore, it is concluded that strains MN07-A0368 ${ }^{\mathrm{T}}$ and MN07-A0371 ${ }^{\mathrm{T}}$ represent two novel species within the genus Actinoplanes, for which the names Actinoplanes toevensis sp. nov. and Actinoplanes tereljensis sp. nov., respectively, are proposed. The epithet pertains to the recovery of the strains from the soil samples of Töv and Terelj, in Mongolia.

Table 3. DNA-DNA hybridization (\%) of strains MN07A0368 ${ }^{\top}$ and $\mathrm{MNO} 7-\mathrm{A} 0371^{\top}$ with phylogenetically closely related type strains of members of the genus Actinoplanes

Immobilized strains: 1 , A. toevensis sp. nov. MN07-A0368 $; 2, A$. tereljensis sp. nov. MN07-A0371 ${ }^{\mathrm{T}}$; 3, A. globisporus NBRC $13912^{\mathrm{T}} ; 4$, A. deccanensis NBRC $13994^{\mathrm{T}} ; 5$, A. brasiliensis NBRC $13938^{\mathrm{T}} ; 6$, A. durhamensis NBRC $14914^{\mathrm{T}} ; 7$, A. ferrugineus NBRC $15555^{\mathrm{T}}$.

\begin{tabular}{|lccccccc|}
\hline Labelled strain & $\mathbf{1}$ & $\mathbf{2}$ & $\mathbf{3}$ & $\mathbf{4}$ & $\mathbf{5}$ & $\mathbf{6}$ & $\mathbf{7}$ \\
\hline 1 & 100 & 42.2 & 30.2 & 24.0 & 21.3 & 46.7 & 17.2 \\
2 & 34.3 & 100 & 24.1 & 17.8 & 21.5 & 56.3 & 12.7 \\
\hline
\end{tabular}

\section{Description of Actinoplanes toevensis sp. nov.}

Actinoplanes toevensis (to.e.ven'sis. N.L. masc. adj. toevensis pertaining to the Mongolian region of Töv Province, where the type strain was isolated).

Aerobic. Gram-stain-positive. Cells grow well on ISP 2, ISP 3, ISP 4, Bennett agar and YS medium, forming welldeveloped, extensively branched and non-fragmented substrate hyphae. A pale pinkish brown soluble pigment is produced on ISP 7 and aerial mycelium is not observed. Numerous globose to oval sporangia are formed on the surface of the water agar, ISP 3, ISP 4 and Bennett agar media; spores formed in the sporangium are motile. Substrate mycelium is moderate yellow brown to orange brown on different agar media. Good growth occurs on ISP 2, ISP 3, ISP 4, Bennett agar and YG agar at $28{ }^{\circ} \mathrm{C}$. Optimal growth is at $25-30{ }^{\circ} \mathrm{C}$; does not grow at $40{ }^{\circ} \mathrm{C}$. Grows at pH 6-11 and tolerates up to $2 \% \mathrm{NaCl}$. Biochemical test results are as follows: catalase is produced; nitrate is not reduced; gelatin, starch, Tween 20 and Tween 80 are hydrolysed, but not urea; and casein and tyrosine are decomposed, but not arbutin, calcium malate, hypo- 
Table 4. Fatty acid composition (\%) of $\mathrm{MNO7-A0368}{ }^{\top}$, MNO7-A0371 ${ }^{\top}$ and strains of related Actinoplanes species

Strains: 1 , A. toevensis sp. nov. MN07-A0368 $; 2$, A. tereljensis sp. nov. MN07-A0371 ${ }^{\mathrm{T}}$; 3, A. ferrugineus NBRC $15555^{\mathrm{T}}$; 4, A. globisporus NBRC $13912^{\mathrm{T}}$; 5, A. brasiliensis NBRC $13938^{\mathrm{T}}$; 6, A. deccanensis NBRC $13994^{\mathrm{T}} ; 7$, A. durhamensis NBRC $14914^{\mathrm{T}}$. Empty cells indicate that the fatty acid was not detected.

\begin{tabular}{|c|c|c|c|c|c|c|c|}
\hline Fatty acid & 1 & 2 & 3 & 4 & 5 & 6 & 7 \\
\hline \multicolumn{8}{|c|}{ Saturated straight-chain } \\
\hline $\mathrm{C}_{14: 0}$ & & & 1.0 & & & & \\
\hline $\mathrm{C}_{15: 0}$ & & 2.3 & 2.3 & 1.0 & 3.0 & & 1.2 \\
\hline $\mathrm{C}_{16: 0}$ & 1.5 & 4.4 & 15.5 & 3.6 & 1.7 & 1.6 & 4.6 \\
\hline $\mathrm{C}_{17: 0}$ & 1.2 & 5.1 & 7.2 & 3.0 & 5.1 & 1.0 & 4.7 \\
\hline $\mathrm{C}_{18: 0}$ & 1.5 & 4.4 & 9.3 & 3.8 & 1.4 & 3.1 & 8.9 \\
\hline \multicolumn{8}{|c|}{ Saturated branched } \\
\hline iso- $\mathrm{C}_{14: 0}$ & & 1.9 & 1.6 & & 1.5 & & 2.0 \\
\hline iso- $\mathrm{C}_{15: 0}$ & 12.6 & 10.6 & 8.4 & 17.6 & 10.1 & 12.6 & 7.3 \\
\hline anteiso- $\mathrm{C}_{15: 0}$ & 11.7 & 11.8 & 22.9 & 3.4 & 24.5 & 10.6 & 12.6 \\
\hline iso- $\mathrm{C}_{16: 0}$ & 21.6 & 18.6 & 7.7 & 20.1 & 17.1 & 20.5 & 19.8 \\
\hline anteiso- $\mathrm{C}_{16: 0}$ & 2.3 & 2.1 & & 1.4 & & & 2.2 \\
\hline$C_{16: 0} 9$-methyl & & & & & & 1.1 & \\
\hline iso- $\mathrm{C}_{16: 0} 2-\mathrm{OH}$ & & 3.4 & & 7.9 & & & 2.3 \\
\hline iso- $\mathrm{C}_{17: 0}$ & 5.0 & 2.4 & 1.1 & 9.7 & 2.1 & 7.3 & 2.1 \\
\hline anteiso- $\mathrm{C}_{17: 0}$ & 24.9 & 15.3 & 13.4 & 10.3 & 18.8 & 34.0 & 20.4 \\
\hline iso- $\mathrm{C}_{17: 0} 2-\mathrm{OH}$ & & 1.0 & & 1.7 & 2.2 & & \\
\hline $\begin{array}{l}\text { anteiso- } \mathrm{C}_{17: 0} 2-\mathrm{OH} \\
\text { Unsaturated }\end{array}$ & 2.5 & 4.6 & & 4.7 & & 1.1 & 2.2 \\
\hline $\mathrm{C}_{16: 1} \omega 9 c$ & & & 1.9 & & & & 1.2 \\
\hline anteiso- $\mathrm{C}_{17: 1}$ & 1.7 & & & & & 1.1 & \\
\hline $\mathrm{C}_{17: 1} \omega 9 c$ & 3.1 & 1.9 & 1.3 & 1.3 & 7.0 & & 1.4 \\
\hline $\mathrm{C}_{18: 1} \omega 9 c$ & 3.6 & 5.0 & 4.6 & 3.9 & 1.9 & 1.0 & 4.6 \\
\hline
\end{tabular}

xanthine, xanthine or adenine. According to the API ZYM assay: positive for alkaline phosphatase, acid phosphatase, naphthol-AS-BI-phosphohydrolase, $\alpha$-mannosidase, cystinearylamidase, $\beta$-galactosidase, $N$-acetyl- $\beta$-glucosaminidase, $\alpha$-fucosidase and $\beta$-glucosidase; weakly positive for esterase lipase (C8); and negative for $\alpha$-chymotrypsin, leucine arylamidase, $\alpha$-glucosidase, esterase (C4), valine arylamidase, $\alpha$-galactosidase, $\beta$-glucuronidase, lipase (C14) and trypsin. According to the API Coryne assay: positive for pyrazinamidase, alkaline phosphatase, $\beta$-galactosidase, $\alpha$-glucosidase, $N$-acetyl- $\beta$-glucosaminidase, $\beta$-glucosidase and urease, hydrolysis of gelatin, D-glucose, D-xylose, maltose, D-lactose, sucrose and glycogen, and catalase; negative for nitrate reduction, pyrrolidonyl arylamidase, $\beta$-glucuronidase, and fermentation of $\mathrm{D}$-ribose and $\mathrm{D}$ mannitol. Peptidoglycan contains 3-hydroxy- and mesoDAP; diagnostic sugars are galactose, glucose, mannose, rhamnose, ribose, xylose and arabinose; mycolic acids are absent. MK- $9\left(\mathrm{H}_{6}\right)$ is the major menaquinone $(97 \%)$; a small amount of MK-9 $\left(\mathrm{H}_{8}\right)$ is also observed (3\%). The polar lipid profile contains diphosphatidylglycerol, phosphatidylethanolamine, phosphatidyl- $N$-methylethylethanolamine and phosphatidylinositol, but phospha- tidylcholine and phosphatidylglycerol are not detected (phospholipid type PII). Major fatty acid methyl esters are anteiso- $\mathrm{C}_{17: 0}$, iso- $\mathrm{C}_{16: 0}$, iso- $\mathrm{C}_{15: 0}$ and anteiso- $\mathrm{C}_{15: 0}$. Detailed fatty acid profiles are given in Table 4.

The type strain is MN07-A0368 ${ }^{\mathrm{T}}$ (=NBRC $105298^{\mathrm{T}}=$ VTCC D9-1 ${ }^{\mathrm{T}}$ ), isolated from soil of Terelj National Park, Töv Province, Mongolia. The DNA G $+\mathrm{C}$ content of the type strain is $70.6 \mathrm{~mol} \%$.

\section{Description of Actinoplanes tereljensis sp. nov.}

Actinoplanes tereljensis (te.rel.jen'sis. N.L. masc. adj. tereljensis pertaining to the Mongolian region of Terelj, where the type strain was isolated).

Aerobic. Gram-stain-positive. Cells grow well on ISP 2, ISP 3 , ISP 7, Bennett agar and YS medium, forming welldeveloped, extensively branched and non-fragmented substrate hyphae. A pale pinkish brown soluble pigment is produced on ISP 7 and aerial mycelium is not observed. Numerous irregular sporangia are formed on the surface of water agar, ISP 3, ISP 4 and Bennett agar media; spores are motile. Substrate mycelium is moderate greyish brown to dark brownish red on different agar media. Good growth occurs on ISP 2, ISP 3, ISP 4, ISP 5, Bennett agar and YG agar at $28{ }^{\circ} \mathrm{C}$. Optimal growth is at $20-28{ }^{\circ} \mathrm{C}$; does not grow at $37{ }^{\circ} \mathrm{C}$. Grows at $\mathrm{pH} 6-9$ and tolerates up to $3 \%$ $\mathrm{NaCl}$. Biochemical test results are as follows: catalase is produced; nitrate is reduced; urea and Tween 20 are hydrolysed, but not gelatin, starch or Tween 80; and casein and tyrosine are decomposed weakly, but not calcium malate, hypoxanthine, xanthine, arbutin or adenine. According to the API ZYM assay: positive for acid phosphatase, cystine arylamidase, $\beta$-galactosidase, $N$ acetyl- $\beta$-glucosaminidase, $\alpha$-fucosidase and $\beta$-glucosidase; weakly positive for alkaline phosphatase, $\alpha$-chymotrypsin, esterase lipase (C8) and naphthol-AS-BI-phosphohydrolase; and negative for leucine arylamidase, $\alpha$-glucosidase, esterase (C4), valine arylamidase, $\alpha$-mannosidase, $\alpha$-galactosidase, $\beta$-glucuronidase, lipase (C14) and trypsin. According to the API Coryne assay: positive for nitrate reduction, pyrazinamidase, alkaline phosphatase, $\beta$-galactosidase, $\alpha$-glucosidase, $N$-acetyl- $\beta$-glucosaminidase and $\beta$ glucosidase, hydrolysis of gelatin, D-glucose, D-xylose, maltose and sucrose, and catalase; weakly positive for fermentation of D-lactose and glycogen; and negative for pyrrolidonyl arylamidase and $\beta$-glucuronidase, and fermentation of D-ribose and D-mannitol. Peptidoglycan contains 3-hydroxy- and meso-DAP; diagnostic sugars are galactose, mannose, ribose, glucose, rhamnose, arabinose and xylose; mycolic acids are absent. MK- $9\left(\mathrm{H}_{6}\right)$ is the major menaquinone $(85 \%)$; a small amount of MK- $9\left(\mathrm{H}_{8}\right)$ is also observed $(15 \%)$. The polar lipid profile contains diphosphatidylglycerol, phosphatidylethanolamine, phosphatidyl- $N$-methylethylethanolamine and phosphatidylinositol, but phosphatidylcholine and phosphatidylglycerol are not detected (phospholipid type PII). Major fatty acid methyl esters are iso- $C_{16: 0}$, anteiso- $C_{17: 0}$, anteiso- $C_{15: 0}$ 
Table 5. Chemotaxonomic characteristics of $M N 07-A 0368^{\top}, M N 07-A 0371^{\top}$ and phylogenetically closely related type strains of members of the genus Actinoplanes

Taxa: 1, A. toevensis sp. nov. MN07-A0368 ${ }^{\mathrm{T}} ; 2$, A. tereljensis sp. nov. MN07-A0371 ${ }^{\mathrm{T}} ; 3$, A. ferrugineus NBRC $15555^{\mathrm{T}} ; 4$, A. globisporus NBRC $13912^{\mathrm{T}}$; 5, A. brasiliensis NBRC $13938^{\mathrm{T}} ; 6$, A. deccanensis NBRC $13994^{\mathrm{T}} ; 7$, A. durhamensis NBRC $14914^{\mathrm{T}}$; 8, genus Actinoplanes. DAP, Diaminopimelic acid.

\begin{tabular}{|c|c|c|c|c|c|c|c|c|}
\hline Character & 1 & 2 & 3 & 4 & 5 & 6 & 7 & 8 \\
\hline DAP & $\begin{array}{l}\text { meso- and } \\
\text { 3-OH-DAP }\end{array}$ & $\begin{array}{l}\text { meso- and } \\
\text { 3-OH-DAP }\end{array}$ & meso-DAP & meso-DAP & meso-DAP & meso-DAP & meso-DAP & $\begin{array}{c}\text { meso-DAP/ } \\
\text { meso- and } \\
\text { 3-OH-DAP }\end{array}$ \\
\hline $\begin{array}{l}\text { Whole cell } \\
\text { sugars }^{\star}\end{array}$ & $\begin{array}{l}\text { Gal, Glu, Man, } \\
\text { Rham, Rib, } \\
\text { Xyl (t), Ara (t) }\end{array}$ & $\begin{array}{l}\text { Gal, Man, Rib, } \\
\text { Glu, Rham, } \\
\text { Ara (t), Xyl (t) }\end{array}$ & $\begin{array}{l}\text { Rib, Gal, Glu, } \\
\text { Man, Ara (t), } \\
\text { Xyl (t) }\end{array}$ & $\begin{array}{l}\text { Glu, Rib, Gal, } \\
\text { Man, Xyl (t), } \\
\text { Ara (t) }\end{array}$ & $\begin{array}{l}\text { Rib, Gal, Glu, } \\
\text { Man, Rham (t), } \\
\text { Xyl (t), Ara (t) }\end{array}$ & $\begin{array}{l}\text { Gal, Rib, Man, } \\
\text { Glu (t), Ara (t), } \\
\text { Xyl (t) }\end{array}$ & $\begin{array}{l}\text { Glu, Rib, Gal, } \\
\text { Man, Ara (t), } \\
\text { Xyl (t) }\end{array}$ & Ara, Xyl \\
\hline Phospholipid(s)† & $\begin{array}{l}\text { PE, DPG, } \\
\text { PME, PI }\end{array}$ & $\begin{array}{l}\text { PE, DPG, } \\
\text { PME, PI }\end{array}$ & $\mathrm{PE}$ & $\mathrm{PE}$ & $\mathrm{PE}$ & $\mathrm{PE}$ & $\mathrm{PE}$ & PE \\
\hline $\begin{array}{l}\text { Cellular fatty } \\
\text { acids }\end{array}$ & $\begin{array}{l}\text { ai- } \mathrm{C}_{17: 0} \\
(24.9 \%), \\
\text { i- } \mathrm{C}_{16: 0} \\
(21.6 \%), \\
\text { i- } \mathrm{C}_{15: 0}(12.6 \%) \text {, } \\
\text { ai-C } \mathrm{C}_{15: 0} \\
(11.7 \%)\end{array}$ & $\begin{array}{l}\text { i- } C_{16: 0}(18.6 \%), \\
\text { ai-C }{ }_{17: 0} \\
(15.3 \%), \\
\text { ai-C } C_{15: 0} \\
(11.8 \%), \\
\text { i-C } C_{15: 0}(10.6 \%)\end{array}$ & $\begin{array}{l}\text { ai- } C_{15: 0} \\
(22.9 \%), \\
C_{16: 0}(15.5 \%), \\
\text { ai- } C_{17: 0} \\
(13.4 \%), \\
C_{18: 0}(9.3 \%)\end{array}$ & $\begin{array}{l}\text { i- } \mathrm{C}_{16: 0} \\
(20.1 \%), \\
\text { i- } \mathrm{C}_{15: 0} \\
(17.6 \%), \\
\text { ai- } \mathrm{C}_{17: 0} \\
(10.3 \%), \\
\text { i- } \mathrm{C}_{17: 0}(9.7 \%)\end{array}$ & $\begin{array}{l}\text { ai-C } \mathrm{C}_{15: 0} \\
(24.3 \%), \\
\text { ai-C } \mathrm{C}_{17: 0} \\
(18.8 \%), \\
\text { i- } \mathrm{C}_{16: 0}(17.1 \%), \\
\text { i-C } \mathrm{C}_{15: 0}(10.1 \%)\end{array}$ & $\begin{array}{l}\text { ai- } C_{17: 0} \\
(34.0 \%), \\
\text { i- } C_{16: 0} \\
(20.5 \%), \\
\text { i- } C_{15: 0} \\
(12.6 \%), \\
\text { ai- } C_{15: 0} \\
(10.6 \%)\end{array}$ & $\begin{array}{l}\text { ai- } \mathrm{C}_{17: 0} \\
(20.4 \%), \\
\text { i- } \mathrm{C}_{16: 0} \\
(19.8 \%), \\
\text { ai- } \mathrm{C}_{15: 0} \\
(12.6 \%), \\
\text { i- } \mathrm{C}_{15: 0}(7.3 \%)\end{array}$ & $\begin{array}{l}\text { ai- } C_{15: 0} \\
C_{17: 0} \\
\text { i- } C_{16: 0} \\
\text { ai- } C_{17: 0} \\
C_{18: 0} \\
C_{19: 0} \\
\text { i- } C_{15: 0} \\
C_{16: 0} \\
C_{18: 1}\end{array}$ \\
\hline Menaquinone(s) & $\begin{array}{l}\text { MK-9 }\left(\mathrm{H}_{6}\right) \\
\text { MK-9 }\left(\mathrm{H}_{8}\right)\end{array}$ & $\begin{array}{l}\text { MK-9 }\left(\mathrm{H}_{6}\right), \\
\text { MK-9 }\left(\mathrm{H}_{8}\right)\end{array}$ & $\begin{array}{l}\text { MK-9 }\left(\mathrm{H}_{6}\right), \\
\left.\text { MK-9( } \mathrm{H}_{8}\right), \\
\text { MK-9 }\left(\mathrm{H}_{4}\right)\end{array}$ & $\begin{array}{l}\text { MK-9 }\left(\mathrm{H}_{6}\right) \\
\text { MK-9 }\left(\mathrm{H}_{8}\right)\end{array}$ & $\begin{array}{r}\text { MK-9 }\left(\mathrm{H}_{4}\right) \\
\text { MK-9 }\left(\mathrm{H}_{6}\right)\end{array}$ & $\begin{array}{l}\text { MK-9 }\left(\mathrm{H}_{4}\right), \\
\text { MK-9 }\left(\mathrm{H}_{2}\right), \\
\text { MK-9( }\left(\mathrm{H}_{6}\right)\end{array}$ & $\begin{array}{c}\text { MK-9 }\left(\mathrm{H}_{6}\right), \\
\text { MK-9 }\left(\mathrm{H}_{8}\right), \\
\text { MK-9 }\left(\mathrm{H}_{4}\right)\end{array}$ & $\begin{array}{l}\text { MK-9 }\left(\mathrm{H}_{4}\right), \\
\text { MK-9 }\left(\mathrm{H}_{6}\right), \\
\text { MK-8 }\left(\mathrm{H}_{2}\right), \\
\text { MK-10 }\left(\mathrm{H}_{4}\right)\end{array}$ \\
\hline $\begin{array}{l}\text { DNA G + C } \\
\text { content }(\mathrm{mol} \%)\end{array}$ & 70.6 & 70.6 & 70.5 & 70.2 & 70.5 & 72.0 & 70.8 & $72-73$ \\
\hline
\end{tabular}

${ }^{\star}$ Gal, Galactose; Glu, glucose; Man, mannose; Rib, ribose; Rham, rhamnose; Ara, arabinose; Xyl, xylose; $t$, trace. $\dagger$ DPG, Diphosphatidylglycerol; PE, phosphatidylethanolamine; PI, phosphatidylinositol; PME, phosphatidyl- $N$-methylethylethanolamine. $\ddagger$ ai, antesio; i, iso.

and iso- $\mathrm{C}_{15: 0}$. Detailed fatty acid profiles are given in Table 4.

The type strain is MN07-A0371 ${ }^{\mathrm{T}}$ (=NBRC $105297^{\mathrm{T}}=$ VTCC D9-10 $10^{\mathrm{T}}$ ), isolated from soil of Terelj National Park, Töv Province, Mongolia. The DNA G $+\mathrm{C}$ content of the type strain is $70.6 \mathrm{~mol} \%$.

\section{Acknowledgements}

This work was conducted under the Joint Research Project between the Department of Biotechnology, NITE, Japan, and the Institute of Biology, Mongolian Academy of Sciences, Mongolia. We acknowledge Dr Tomohiko Tamura for the scientific advice, Ms Yayoi Sakiyama for technical assistance and Dr Manabu Suto for the collection of samples from Mongolia.

\section{References}

Altschul, S. F., Gish, W., Miller, W., Myers, E. W. \& Lipman, D. J. (1990). Basic local alignment search tool. J Mol Biol 215, 403410.

Eck, R. V. \& Dayhoff, M. O. (1966). Atlas of Protein Sequences and Structure. Silver Springs, MD: National Biomedical Research Foundation.
Ezaki, T., Hashimoto, Y., Takeuchi, N., Yamamoto, H., Liu, S. L. Miura, H., Matsui, K. \& Yabuuchi, E. (1988). Simple genetic method to identify viridans group streptococci by colorimetric dot hybridization and quantitative fluorometric hybridization in microdilution wells. J Clin Microbiol 26, 1708-1713.

Ezaki, T., Hashimoto, Y. \& Yabuuchi, E. (1989). Fluorometric deoxyribonucleic acid-deoxyribonucleic acid hybridization in microdilution wells as an alternative to membrane filter hybridization in which radioisotopes are used to determine genetic relatedness among bacterial strains. Int J Syst Bacteriol 39, 224-229.

Felsenstein, J. (1985). Confidence limits on phylogenies: an approach using the bootstrap. Evolution 39, 783-791.

Goodfellow, M., Stanton, L. J., Simpson, K. E. \& Minnikin, D. E. (1990). Numerical and chemical classification of Actinoplanes and some related actinomycetes. J Gen Microbiol 136, 19-36.

Gordon, R. E. \& Mihm, J. M. (1957). A comparative study of some strains received as nocardiae. J Bacteriol 73, 15-27.

Gordon, R. E., Barnett, D. A., Handerhan, J. E. \& Pang, C. H.-N. (1974). Nocardia coeliaca, Nocardia autotrophica, and the nocardin strain. Int J Syst Bacteriol 24, 54-63.

Hayakawa, M. \& Nonomura, H. (1987). Humic acid-vitamin agar, a new medium for selective isolation of soil actinomycetes. J Ferment Technol 65, 501-509.

Hayakawa, M., Otoguro, M., Takeuchi, T., Yamazaki, T. \& limura, Y. (2000). Application of a method incorporating differential centrifu- 
gation for selective isolation of motile actinomycetes in soil and plant litter. Antonie van Leeuwenhoek 78, 171-185.

Humble, M. W., King, A. \& Phillips, I. (1997). API ZYM: a simple rapid system for the detection of bacterial enzymes. J Clin Pathol 30, 275277.

Jones, K. L. (1949). Fresh isolates of actinomycetes in which the presence of sporogenous aerial mycelia is a fluctuating characteristic. J Bacteriol 57, 141-145.

Kloos, W. E., Tornabene, T. G. \& Schleifer, K. H. (1974). Isolation and characterization of Micrococci from human skin, including two new species: Micrococcus lylae and Micrococcus kristinae. Int J Syst Bacteriol 24, 79-101.

Lechevalier, M. P., De Bièvre, C. \& Lechevalier, H. A. (1977), Chemotaxonomy of aerobic actinomycetes: phospholipid composition. Biochem Syst Ecol 5, 249-260.

Marmur, J. (1961). A procedure for the isolation of deoxyribonucleic acid from microorganisms. J Mol Biol 3, 208-218.

Mesbah, M., Premachandran, U. \& Whitman, W. B. (1989). Precise measurement of the $\mathrm{G}+\mathrm{C}$ content of deoxyribonucleic acid by highperformance liquid chromatography. Int J Syst Bacteriol 39, 159-167.

Minnikin, D. E., O'Donnell, A. G., Goodfellow, M., Alderson, G., Athalye, M., Schaal, A. \& Parlett, J. H. (1984). An integrated procedure for the extraction of bacterial isoprenoid quinones and polar lipids. J Microbiol Methods 2, 233-241.

Norovsuren, Zh., Zenova, G. M. \& Mosina, L. V. (2007). Actinomycetes in the rhizosphere of semidesert soils of Mongolia. Eur Soil Sci 40, 415-418.

Nozawa, Y., Sakai, N., Arai, K., Kawasaki, Y. \& Harada, K. (2007). Reliable and sensitive analysis of amino acids in the peptidoglycan of actinomycetes using the advance Marfey's method. J Microbiol Methods 70, 306-311.

Rayner, R. W. (1970). A Mycological Colour Chart. Kew, UK: Commonwealth Mycological Institute and British Mycological Society.

Rzhetsky, A. \& Nei, M. (1992). A simple method for estimating and testing minimum evolution trees. Mol Biol Evol 9, 945-967.
Saito, H. \& Miura, K. (1963). Preparation of transforming deoxyribonucleic acid by phenol treatment. Biochim Biophys Acta 72, 619-629.

Saitou, N. \& Nei, M. (1987). The neighbor-joining method: a new method for reconstructing phylogenetic tree. Mol Biol Evol 4, 406425.

Sasser, M. (1990). Identification of bacteria by gas chromatography of cellular fatty acids, MIDI Technical Note 101. Newark, DE: MIDI Inc.

Shirling, E. B. \& Gottlieb, D. (1966). Methods for characterization of Streptomyces species. Int J Syst Bacteriol 16, 313-340.

Staneck, J. L. \& Roberts, G. D. (1974). Simplified approach to identification of aerobic actinomycetes by thin-layer chromatography. Appl Microbiol 28, 226-231.

Tamura, T. \& Hatano, K. (2001). Phylogenetic analysis of the genus Actinoplanes and transfer of Actinoplanes minutisporangius Ruan et al. 1986 and 'Actinoplanes aurantiacus' to Cryptosporangium minutisporangium comb. nov. and Cryptosporangium aurantiacum sp. nov. Int J Syst Evol Microbiol 51, 2119-2125.

Tamura, T., Nakagaito, Y., Nishii, T., Hasegawa, T., Stackebrandt, E. \& Yokota, A. (1994). A new genus of the order Actinomycetales, Couchioplanes gen. nov., with descriptions of Couchioplanes caeruleus (Horan and Brodsky 1986) comb. nov. and Couchioplanes caeruleus subsp. azureus subsp. nov. Int J Syst Bacteriol 44, 193-203.

Tamura, K., Nei, M. \& Kumar, S. (2004). Prospects of inferring very large phylogenies by using the neighbor-joining method. Proc Natl Acad Sci U S A 101, 11030-11035.

Tamura, K., Dudley, J., Nei, M. \& Kumar, S. (2007). MEGA4: Molecular Evolutionary Genetics Analysis (MEGA) software version 4.0. Mol Biol Evol 24, 1596-1599.

Thompson, J. D., Gibson, T. J., Plewniak, F., Jeanmougin, F. \& Higgins, D. G. (1997). The CLUSTAL_X windows interface: flexible strategies for multiple sequence alignment aided by quality analysis tools. Nucleic Acids Res 25, 4876-4882.

Wayne, L. G., Brenner, D. J., Colwell, R. R., Grimont, P. A. D., Kandler, O., Krichevsky, M. I., Moore, L. H., Moore, W. E. C., Murray, R. G. E. \& other authors (1987). International Committee on Systematic Bacteriology. Report of the ad hoc committee on reconciliation of approaches to bacterial systematics. Int J Syst Bacteriol 37, 463-464. 